\title{
Etablert, utprøvende eller eksperimentell?
}

Åpen kirurgisk implantasjon av aortaventil er en effektiv og etablert behandling for symptomgivende aortastenose. En stor andel av pasientene med denne tilstanden er ikke egnet for åpen kirurgisk behandling på grunn av høy alder, nedsatt venstre ventrikkel-funksjon eller betydelig komorbiditet. Transkateter aortaventilimplantasjon (TAVI) er en mindre invasiv metode hvor det gjøres ballongdilatasjon av den syke klaffen og en kunstig aortaklaff føres på plass og implanteres på bankende hjerte ved hjelp av et kateter i lysken eller via apeks av hjertet. Denne metoden har siden 2002 vært tilbudt selekterte pasienter som har høy operativ risiko.

Innføringen av kateterbasert implantasjon av aortaklaffer i Norge var kontroversiell. Feiringklinikken behandlet ti pasienter i 2008 før virksomheten ble stanset etter to postoperative dødsfall (1). Kunnskapssenteret konkluderte samme år med at metoden var lovende, men at dokumentasjonen av klinisk effekt og sikkerhet var begrenset (2). Nasjonalt råd for kvalitet og prioritering i helsetjenesten fastslo i 2008 at kateterbasert implantasjon av aortaklaffer var eksperimentell behandling og anbefalte at et eventuelt behandlingstilbud burde gis i form av inklusjon i kliniske studier (3). Denne innstillingen sto i motsetning til høringsuttalelser fra det thoraxkirurgiske, kardiologiske og radiologiske miljøet, som pekte på at metoden var etablert og godt utprøvd ved flere utenlandske sentre. I 2009 mottok Fylkeslegen i Oslo og Akershus en bekymringsmelding hvor det ifølge en artikkel i Aftenposten het «Det var en faglig disputt om denne behandlingen av kritisk syke pasienter var eksperimentell, eller om den kunne ansees som en naturlig medisinsk utvikling av faget» (1). Det er en skillelinje som ikke er lett å trekke.

Steigen og medarbeidere presenterer i dette nummer av Tidsskriftet de første erfaringer med kateterbasert implantasjon av aortaklaffer fra Universitetssykehuset Nord-Norge (4). Forfatterne foretok kateterbasert implantasjon av aortaklaffer hos 25 eldre med alvorlig symptomgivende aortastenose som var uegnet for konvensjonell åpen kirurgi. Denne gruppen ble sammenliknet med 25 høyrisikopasienter i samme aldersgruppe som ble operert med konvensjonell åpen kirurgi. De konkluderer med at korttidsresultatene ved kateterbasert implantasjon av aortaklaffer er likeverdige eller bedre enn resultatene etter konvensjonell kirurgisk behandling, og at metoden er egnet for eldre pasienter med symptomgivende aortastenose hvor åpen kirurgi ville innebære uakseptabelt høy risiko.

Det var ikke tvil om at behandlingen ble gjort etter grundige forberedelser og holdt høy faglig standard. Likevel ble de etiske sidene ved manuskriptet diskutert på flere redaksjonsmøter i Tidsskriftet. Hva var problemet? Forfatterne hadde ikke søkt godkjenning fra regional etisk komité før behandlingen ble tilbudt pasientene - med den begrunnelse at de anså metoden som «utprøvende behandling», ikke som «eksperimentell behandling» og at studien etter deres mening derfor ikke var fremleggingspliktig for regional etisk komité. Av samme grunn mente de at registrering $\mathrm{i}$ et studieregister ikke var nødvendig. På den annen side valgte forfatterne likevel å innhente skriftlig informert samtykke fra pasientene, noe som ble begrunnet med innstillingen fra Nasjonalt råd for kvalitet og prioritering $\mathrm{i}$ helsetjenesten og at man anså metoden for «utprøvende behandling». Begrepene «eksperimentell behandling» og «utprøvende behandling» er definert i forskrift om prioritering av helsetjenester som henholdsvis «udokumentert behandling som ikke er ledd i kontrollerte undersøkelser, og hvor virkning, risiko og bivirkninger er ukjent eller ufullstendig klarlagt» og «behandling som utprøves som ledd i en vitenskapelig studie, men der kravene til fullverdig dokumentasjon i forhold til etablert behandling ennå ikke er tilfredsstillende». Retten til nødvendig helsehjelp omfatter bare etablert behandling, ikke eksperimentell eller utprøvende behandling. Disse begrepene er uklare (5) og ikke velegnet til å skille forskning, med sine formelle krav til etisk godkjenning, fra intern kvalitetssikring. Tidsskriftet krever at forskning skal være godkjent av en regional etisk komité (6) og at en klinisk studie skal være registrert i et godkjent studieregister før studiestart (7). Vi mener at forfatterne burde ha forelagt studien for regional etisk komité. Et viktig prinsipp er at en uavhengig part, ikke forskerne selv, skal avgjøre om en ny behandling er etisk forsvarlig eller ikke. Vi kom til at dette hensynet delvis var ivaretatt ved at behandlingen var vurdert av klinisk etisk komité ved det aktuelle sykehuset og fordi det var innhentet skriftlig samtykke fra pasientene. Vi valgte derfor etter en helhetsvurdering og under sterk tvil å publisere manuskriptet.

I en nylig publisert prospektiv multisenterstudie ble 358 pasienter med alvorlig aortastenose som ikke var kandidater for kirurgisk behandling randomisert til enten kateterbasert implantasjon av aortaklaffer eller standard terapi (8). Oppfølging etter ett år viste at de som ble behandlet med kateterbasert implantasjon av aortaklaffer, hadde betydelig lavere dødelighet og færre sykehusinnleggelser enn kontrollgruppen. På den annen side var det en høyere andel alvorlige hjerneslag og vaskulære hendelser i gruppen som fikk aortaventil. Disse komplikasjonene ble ikke påvist i studien til Steigen og medarbeidere. Dette illustrerer behovet for at klinisk effekt og sikkerhet ved nye metoder utprøves i tilstrekkelig store prospektive randomiserte studier.

\section{Lars Frich}

lars.frich@legeforeningen.no

Lars Frich (f. 1966) er dr.med., medisinsk redaktør i Tidsskriftet og lege i spesialisering ved Kirurgisk avdeling, Oslo universitetssykehus.

\section{Oppgitte interessekonflikter: Ingen}

\section{Litteratur}

1. Gedde-Dahl S. Hjertepasient døde i omstridt behandling. Aftenposten 2.7.2009: $2-3$

2. Lauvrak V, Ørjasæter Elvsaas I, Samdal K. Kateterbasert implantasjon av aortaklaffer. Metodevarsel nummer 3. Oslo: Kunnskapssenteret, 2008.

3. Sak 08/130. Kateterbasert implantasjon av hjerteklaffer. Nasjonalt råd for kvalitet og prioritering i helsetjenesten, 2008. www.kvalitetog prioritering.no/Saker/ 12355.cms (7.12.2010).

4. Steigen TK, Schive B, Næsheim T et al. Transkateter aortaventilimplantasjon ved aortastenose. Tidsskr Nor Legeforen 2011; 131: 343-8.

5. Sak 09/64. Fra «eksperimentell» via «utprøvende»til «etablert behandling».. Nasjonalt råd for kvalitet og prioritering i helsetjenesten, 2009. www.kvalitetogprioritering.no/Saker/12765.cms (7.12.2010)

6. Haug C. Bare spør! Tidsskr Nor Legeforen 2010; 130: 1445.

7. Bretthauer M, Haug C. Uten registrering, ingen publisering! Tidsskr Nor Legeforen 2009; 129: 733.

8. Leon MB, Smith CR, Mack M et al. Transcatheter aortic-valve implantation for aortic stenosis in patients who cannot undergo surgery. N Engl J Med 2010; 363 1597-607. 